\title{
Threadbar Bolts in a Seismically Active, High Stress, High Yield Environment-Otter-Juan Mine, Kambalda
}

\author{
M.H. Turner AMC Consultants, Western Australia \\ T. Green Goldfields Mine Management, Otter-Juan Mine, Western Australia
}

The Otter-Juan Mine is one of the oldest mines in the Kambalda region and operations recently extended beyond 1200 mbs, making it one of the deepest mines in Western Australia. Virgin stresses are very high, and many of the excavations developed close to and within the orebody are located within a weak talc-chlorite ultramafic rockmass.

The stope and development designs, extraction sequence and support systems are all adjusted to minimise the effects of stress redistribution. The primary methods of controlling the effects of stress have been the conversion to an airleg-based stoping method to reduce orebody excavation widths, stoping heights and dilution, the introduction of an extraction sequence to minimise stress 'hotspots' and the use of Threadbar bolts ('Gewi bars').

The bolts have performed exceptionally well in extreme conditions and have formed the backbone of a relatively low cost and simple ground support system capable of yielding with the rockmass deformations and seismicity associated with mining at depth.

This paper discusses the technical aspects, mine designs and test results relating bolt performance to underground conditions.

\section{LOCATION AND GEOLOGY}

The Otter-Juan Mine is located to the north of Kambalda town, approximately $60 \mathrm{~km}$ south of Kalgoorlie in Western Australia (Figure 1). The mine was operated by WMC Resources (WMC) from 1969 to 1999, and was re-opened in May 2001 by Goldfields Mine Management Pty Ltd (GMM), who have sub-leased the mine from WMC.

Since 1966, the Kambalda Dome has produced over 25.7 million tonnes of ore at an average grade of $3.24 \%$ nickel from 10 separate mines (updated from Banasik, 2003). Cumulative production from Otter-Juan is expected to have exceeded over 8 million tonnes by November 2004, making the mine by far the most significant and consistent producer in the region. The average grade produced to date has been over $3.5 \% \mathrm{Ni}$ for a contained nickel metal production of over 280,000 tonnes (updated from Banasik, 2003).

The Otter-Juan Mine is located on the northwest boundary of the Kambalda Dome (Figure 2). The ore surfaces at OtterJuan are hosted in the Kambalda Komatiite Formation, immediately in contact with, or contained within the underlying basalt. Currently the majority of production is sourced from the Edwards Lode, which is the deepest and most northerly lode at Otter-Juan, and is also the most northerly known orebody on the Kambalda Dome.

Typically in the centre of the main Edwards Lode there is a layer of massive ore immediately above the basalt with a thickness of around $0.8 \mathrm{~m}$. Above the massive ore is a 1.2 metre thick layer of matrix and overlying this unit is a disseminated ore layer up to 0.5 metre in thickness. The hangingwall is a talc-magnesite-chlorite ultramafic rock unit.

Currently two orebodies are being mined in the lower sections of the Edwards Lode, a lower surface (F) and an upper surface $(\mathrm{N})$, with a vertical separation of approximately $20 \mathrm{~m}$. The Edwards Lode typically dips at $25^{\circ}$ to the North, with a strike length of $150 \mathrm{~m}$ and orebody widths of around $2 \mathrm{~m}$. Current operations extend below $1200 \mathrm{mbs}$, making Otter-Juan one of the deepest mines in WA.

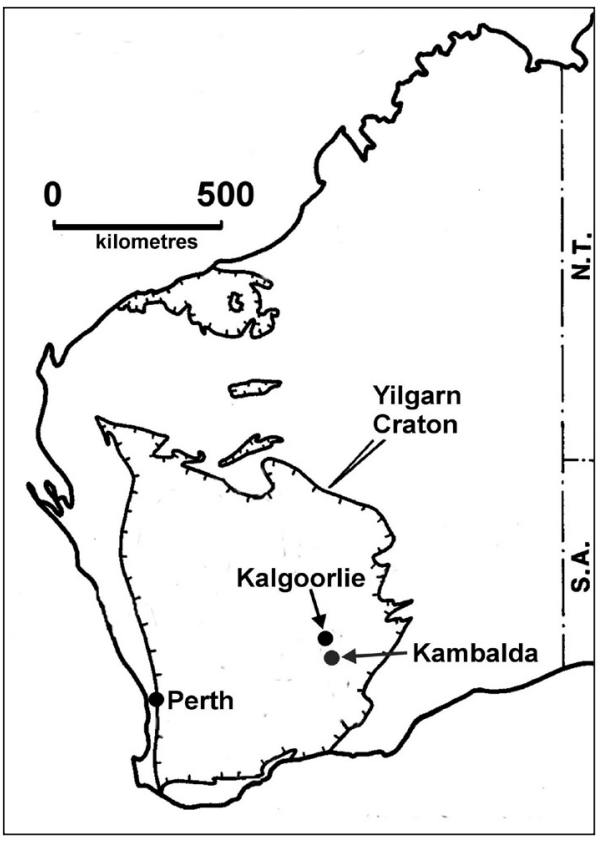

FIG. 1 Location Map

\section{GEOTECHNICAL ENVIRONMENT}

The deep Otter-Juan ore surfaces are typical of the Kambalda nickel deposits, generally having a very competent basalt footwall and a poor talc-magnesite-chlorite ultramafic hangingwall. The majority of the matrix and disseminated ore consists of ultramafic material with minor sulphide mineralisation, generally far weaker than the basalt but more competent than the very weak hangingwall. The hangingwall ultramafic, matrix and disseminated ore tend to deform and exhibit 'creep' under the high-stress conditions experienced in the lower sections of Otter-Juan. 


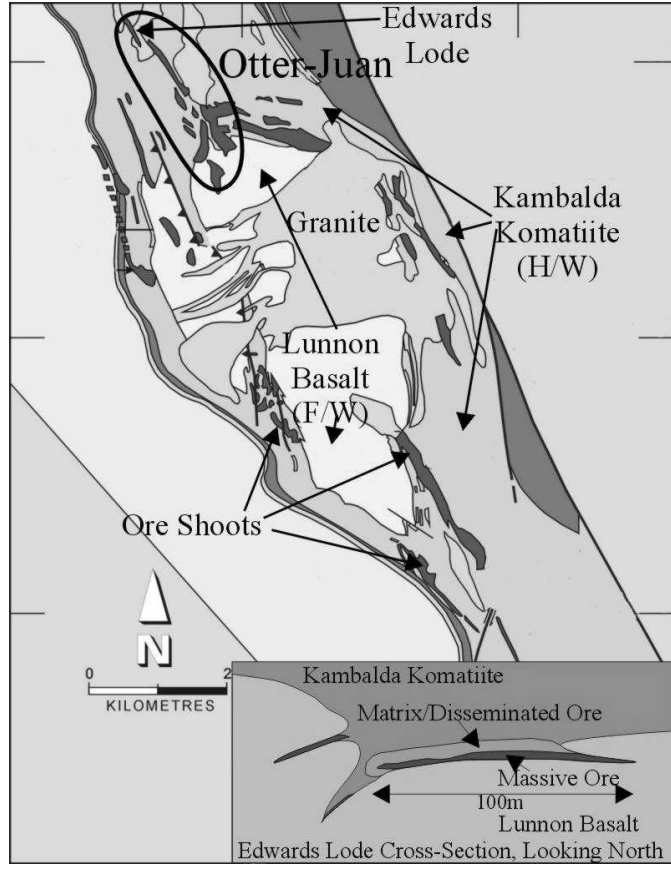

FIG. 2 Kambalda Dome geology

\subsection{Rockmass Properties}

The intact strengths of the talc-magnesite-chlorite ultramafic units in the orebody hangingwall (Table 1) are considerably below the level of virgin stress (Table 2). Note also that the intact rock testing results for ultramafic do not include the very weak talc-chlorite material, which for other mines in the Kambalda region typically range from UCS values of 23 to $40 \mathrm{MPa}$.

TABLE 1 Intact rock property summary

\begin{tabular}{lcccc}
\hline Rock Type & $\begin{array}{c}\text { UCS } \\
(\mathrm{MPa})\end{array}$ & $\begin{array}{c}\text { Young's } \\
\text { Modulus } \\
(\mathrm{GPa})\end{array}$ & $\begin{array}{c}\text { Poisson's } \\
\text { Ratio }\end{array}$ & $\begin{array}{c}\text { Density } \\
\left(\mathrm{kg} / \mathrm{m}^{3}\right)\end{array}$ \\
\hline Massive Sulphide & 140 & 51 & 0.12 & 4.85 \\
Basalt & 275 & 80 & 0.22 & 2.96 \\
Ultramafic & 76 & 53 & 0.36 & 2.90 \\
\hline
\end{tabular}

\subsection{Stress Environment}

In situ stress measurements were undertaken around 31 Level at Otter-Juan using the CSIR Hollow Inclusion (HI) cell technique. The results (Table 2, AMC, 1998) indicate a very high increase in stress with depth, as is typical in some sections of the Kambalda-Kalgoorlie region of the Yilgarn Craton in Western Australia (Lee et al., 2001). Mining induced stress changes are also significant due to the pillar stoping method. The high stresses tend to cause pillar failure as soon as pillars are exposed with widths of less than $6 \mathrm{~m}$. This is currently beneficial, with the support system coping with the rockmass deformations and the rockmass incapable of storing sufficient energy to generate damaging seismicity.

\section{MINING METHOD}

The orebodies are extracted using airleg slot-stoping. The method involves initial ore drive development using jumbos, followed by airleg slot rises, cross-cuts and finally pillar stripping (Figure 3). A plot of the actual F-Surface voids is included in Figure 4 (the upper N-surface has been omitted for more clarity).
TABLE 2 Virgin stress regime (AMC, 1998)

\begin{tabular}{lccc}
\hline Location & $\begin{array}{c}\text { Major } \\
\text { Principal } \\
\text { Stress }\end{array}$ & $\begin{array}{c}\text { Minor } \\
\text { Principal } \\
\text { Stress }\end{array}$ & $\begin{array}{c}\text { Stress Increase } \\
\text { per Metre }\end{array}$ \\
\hline 31 Level 980mbs & $68.6 \mathrm{MPa}$ & $36 \mathrm{MPa}$ & $0.07 \mathrm{MPa}$ \\
$1200 \mathrm{mbs}$ & $84 \mathrm{MPa}$ & $43 \mathrm{MPa}$ & $0.07 \mathrm{MPa}$ \\
$1400 \mathrm{mbs}$ & $98 \mathrm{MPa}$ & $51 \mathrm{MPa}$ & $0.07 \mathrm{MPa}$ \\
\hline
\end{tabular}
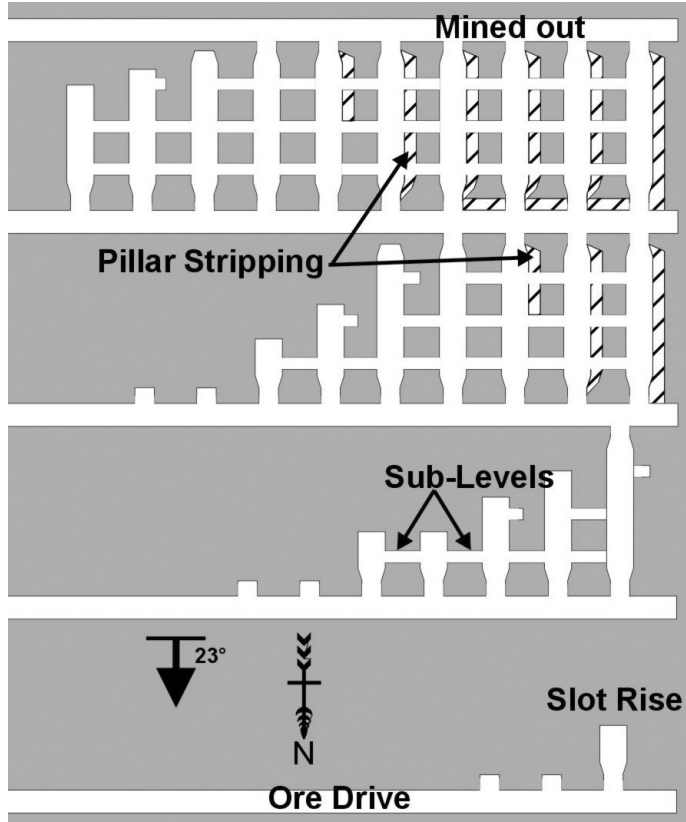

FIG. 3 Stoping layout and extraction sequence

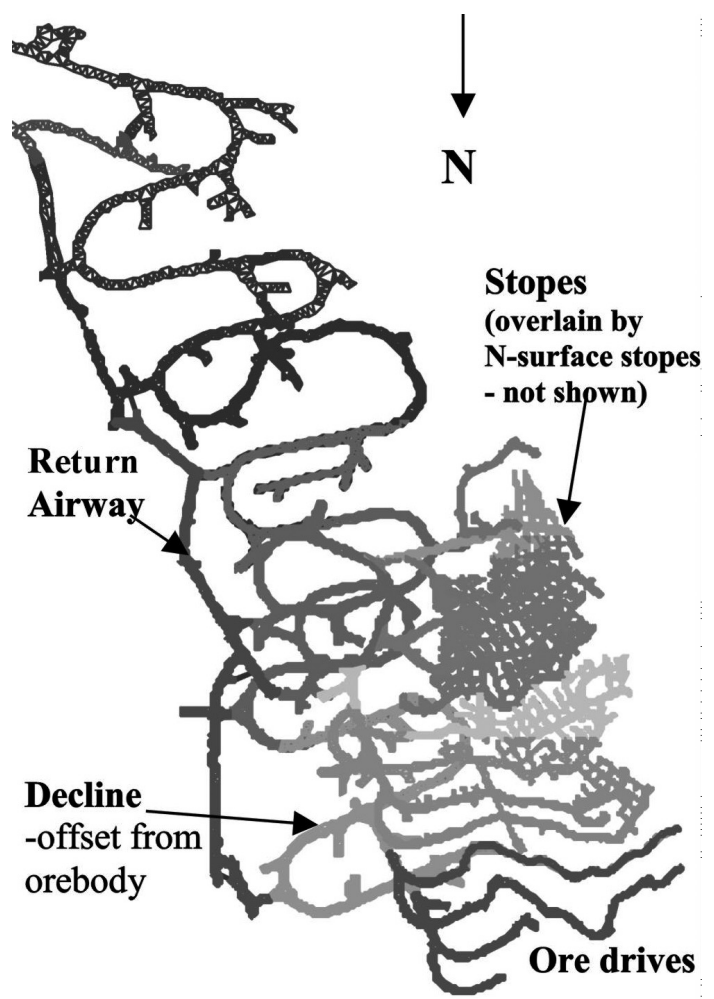

FIG. 4 Lower F-Surface plan 
Figure 3 shows the idealised stope design and extraction sequence involving an overall top-down, west-east mining direction. Access to the ore drives is from the East to eliminate the formation of any shrinking pillars and the decline is located below the eastern boundary for the same reason. Figure 4 also shows the variability of the orebody along strike and down-dip.

The airleg mining method used at Otter-Juan has recently been documented in greater detail by Turner, et al., 2004.

\section{SUPPORT SYSTEMS}

Ore drives developed through the ultramafic are currently supported with standard split sets and mesh installed by the jumbo prior to boring each cut. Since Goldfields Mine Management reopened the mine in May 2001, the ore drives have also been supported with Threadbar Bolts (locally called 'Gewi bars'), as a secondary support system (Figure 5).

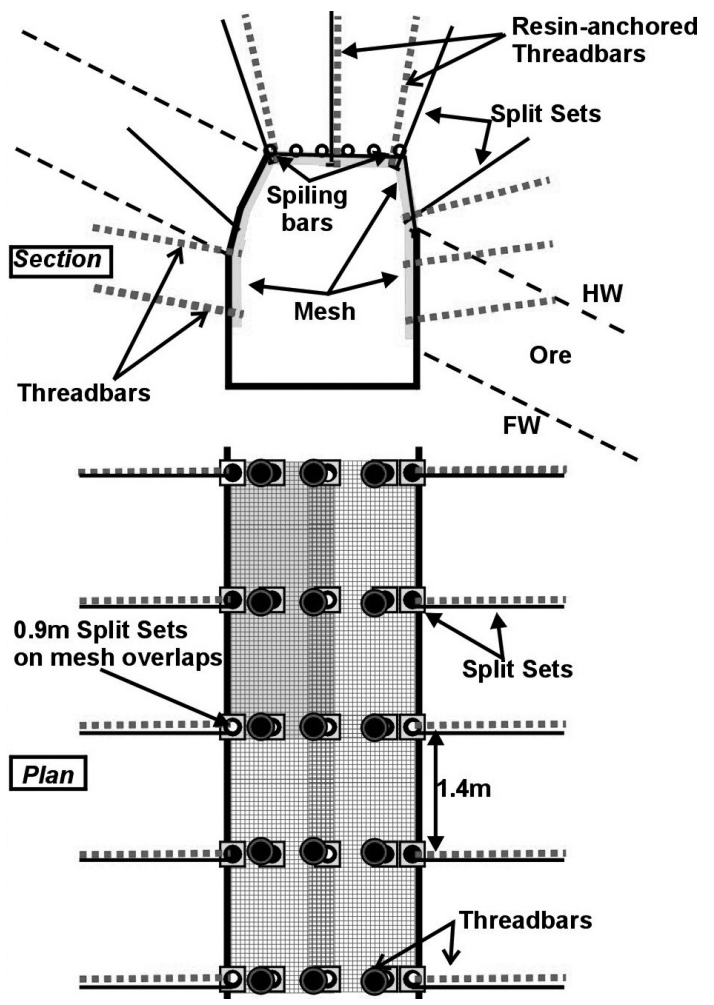

FIG. 5 Ore drive support

The Threadbars are installed by airleg miners following completion of the ore drive development and prior to development of the slot rises. Once production slot rises are developed up from these ore drives, the stress levels increase and deformation of the walls and backs increases to levels where split set ring failure regularly occurs before stoping has been completed.

Slot rises and other stoping excavations are supported with Threadbar bolts and medium gauge mesh (4 mm $\times 50 \mathrm{~mm} \times 75 \mathrm{~mm}$ ) (Figure 6). Threadbars are installed in slot walls to prevent unravelling of the walls as the pillars yield (Figures 6, 7 and 8), and also into the face to control loose slabs generated by stress fracturing.

\subsection{Threadbar Bolts}

The Threadbars used at Otter-Juan are all installed by airleg miners with a single resin capsule in a $28 \mathrm{~mm}$ hole. The bolts are supplied by Dywidag-Systems International Pty Ltd (DSI). The $20 \mathrm{~mm}$ diameter bolts are made of 550/650 MPa mild steel with a quoted yield capability of 16 to $19 \%$ and a
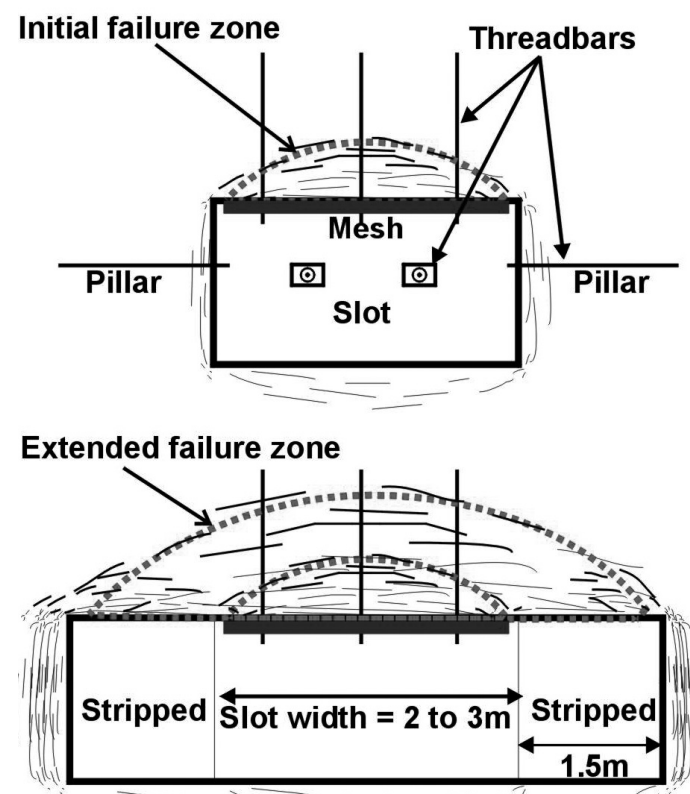

Looking up-dip (South)

FIG. 6 Stope slot rise support and design

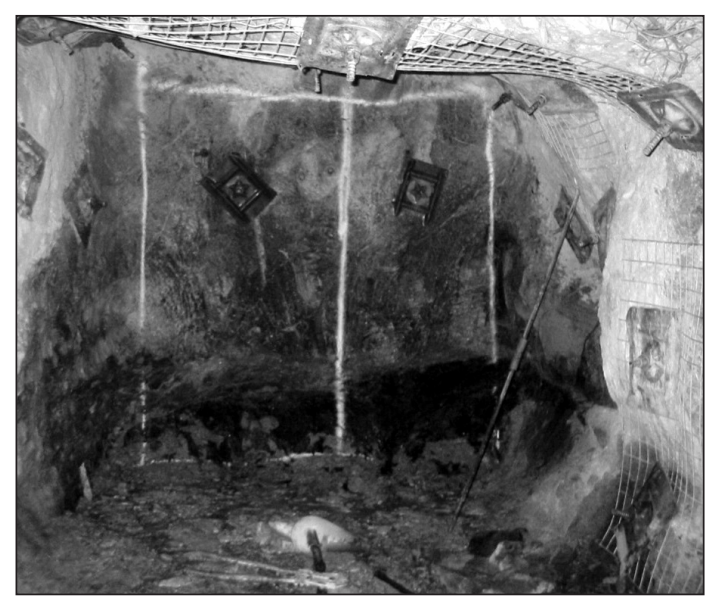

FIG. 7 Hangingwall, face and wall Threadbars in typical slot

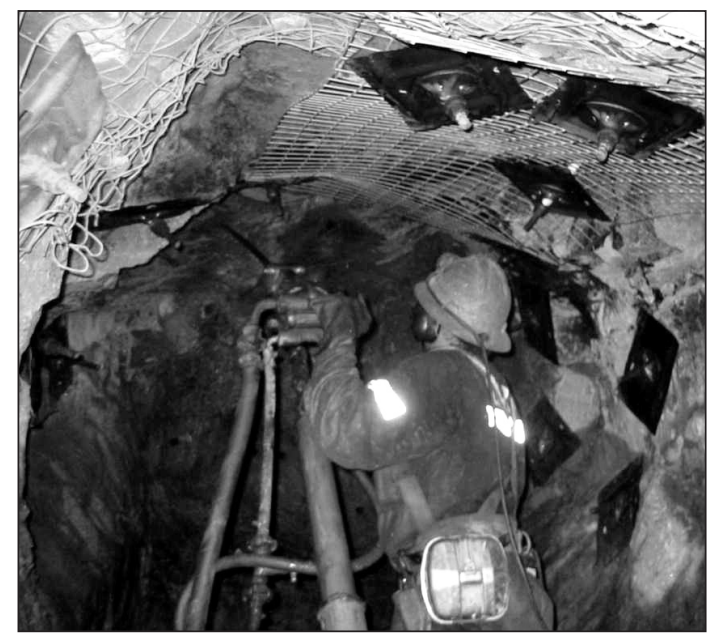

FIG. 8 Miner boring face in supported narrow slot 
yield load of $160 \mathrm{kN}$ (DSI, 2004). The bars have a hot-rolled coarse left-hand thread with a $10 \mathrm{~mm}$ pitch over the whole length of the bar (Figure 9). The ability to cope with relatively high levels of elongation is critical for the success of the bolts in the high rockmass deformation environment at OtterJuan.

The holes for $2.4 \mathrm{~m}$ bolts are drilled $2.2 \mathrm{~m}$ long. A single 600 $\mathrm{mm} \times 20 \mathrm{~mm}$ medium set Minova resin capsule is attached to the end of the Threadbar with a cardboard sleeve before being inserted up the hole.

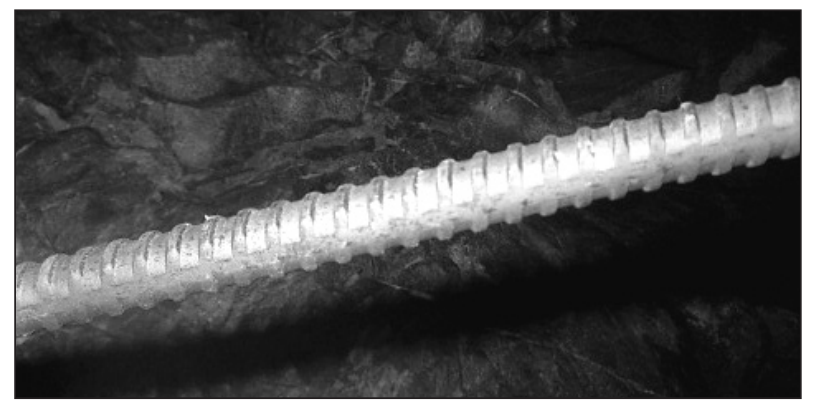

FIG. 9 Threadbar

The Threadbar is fixed within a special chuck adaptor that allows the bar to be spun with the airleg machine. The airleg machines are Boarmax rockdrills, made in Poland and distributed in Australia by DownUnder Mining. The airlegs are made by SIG. The nut is screwed on and the bolt tensioned with a compressed air powered impact wrench.

The Threadbars are installed with a single $600 \mathrm{~mm}$ resin capsule which results in only $0.5 \mathrm{~m}$ of resin-bonded length, leaving approximately $1.7 \mathrm{~m}$ without resin. Test results from the manufacturer indicate a capacity of 19\% elongation (DSI, 2004) resulting in a 'yield' capacity of over $0.3 \mathrm{~m}$. Underground pull-test results for a representative Threadbar relative to a representative Cone bolt are shown in Figure 10 (Player, 2004). The results for deformations up to $65 \mathrm{~mm}$ indicate that the performance of Threadbars slightly exceeds that of Cone Bolts (for the examples available). Cone Bolts were specifically designed for rockburst conditions, but Threadbars appear to be a viable alternative in slight to moderate seismic conditions, from experience gained at Otter-Juan.

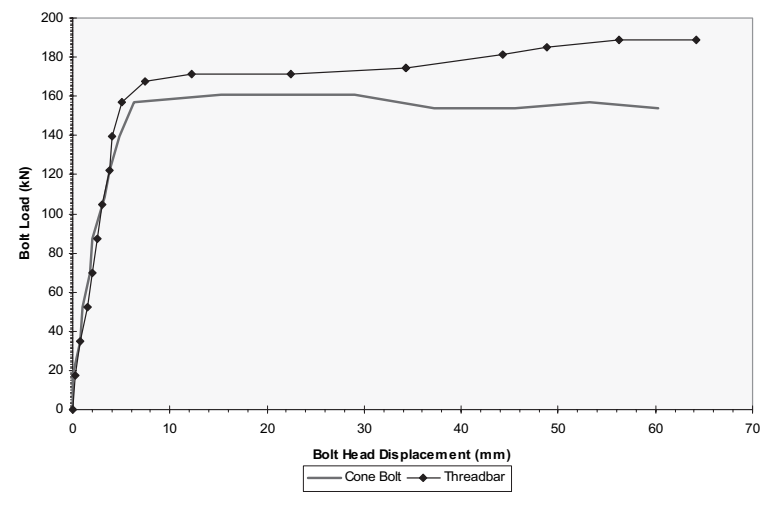

FIG. 10 Load deformation performance, Threadbar and Cone bolt (Player, 2004)

Major advantages of resin-installed Threadbars over cement grouted Cone bolts include low cost and the ability to immediately install mesh at the face due to the use of resin (installing mesh with Cone bolts involves an 8 hour delay whilst the cement grout cures).

\subsection{Mesh}

The mesh that the airleg miners are installing is Galvanised $4.00 \mathrm{~mm}$ Weldmesh made by Smorgon ARC, with a product code of ES45075. The mesh incorporates $4 \mathrm{~mm}$ wire and $50 \mathrm{~mm}$ by $75 \mathrm{~mm}$ centres, and the sheets are $1.2 \mathrm{~m}$ by $2.4 \mathrm{~m}$, with each sheet weighing 10.2 kilograms. The weight of the mesh sheets is such that airleg miners can install the sheets on their own.

The mesh has been tested on site by loading with $600 \mathrm{~kg}$ between 4 bolts at $1.5 \times 1.5 \mathrm{~m}$ spacing - the mesh did not fail on the strands or welds. The test was undertaken by loading cement bags onto the sheet of mesh. The on-site test was undertaken as there was no test certificate available from the manufacturers at the time the mesh was required underground.

\subsection{Support Costs}

The unit costs for supporting with Threadbars are relatively cheap (Table 3), but the overall mining costs, due mainly to labour, are high. The production cost per tonne is currently around $\$ 61$, which includes all stoping related costs plus costs for strike driving on ore. Each airleg miner in the stope slots typically spends around 2 hours per shift installing support. This would include 6 Threadbars bolts plus a single sheet of mesh in the backs, 4 bolts in the slot walls, and 2 into the face.

\section{TABLE 3 Support unit costs}

\begin{tabular}{|c|c|c|}
\hline Item & Details & Cost $(A \$)$ \\
\hline Threadbar Bolt & $550 \mathrm{MPa}, 2.4 \mathrm{~m}, 20 \mathrm{~mm}$ & 7.20 \\
\hline $\begin{array}{l}\text { Nut and 'Star' type } \\
\text { Domed Washer }\end{array}$ & $150 \mathrm{~mm} \times 4 \mathrm{~mm}$ & 1.30 \\
\hline Dragonfly Plate/Washer & $350 \mathrm{~mm} \times 300 \mathrm{~mm} \times 3 \mathrm{~mm}$ & 4.48 \\
\hline $\begin{array}{l}\text { Minova Medium Set } \\
\text { Resin capsule }\end{array}$ & $600 \mathrm{~mm} \times 20 \mathrm{~mm}$ & 1.84 \\
\hline $\begin{array}{l}\text { Mesh } \\
1.2 \mathrm{~m} \times 2.4 \mathrm{~m}\end{array}$ & $\begin{array}{l}\text { ES45075, Weldmesh } \\
\text { Galvanised, } 4.00 \mathrm{~mm} \\
\text { wire, } 50 \mathrm{~mm} \times 75 \mathrm{~mm}\end{array}$ & 40.0 \\
\hline
\end{tabular}

\section{ROCKMASS DEFORMATION}

The orebody and hangingwall ultramafic rocks sometimes exhibit significant deformation during the mining cycle.

Deformations in ore drive excavations prior to airleg slot rise development are suited to split sets and mesh, as installed by the jumbos. Once the airleg slots are broken away however, deformations in the backs and walls of the ore drives quickly exceed the capabilities of split sets when combined with clamping of bolts in shear.

\subsection{Stope Closure}

Vertical stope closure of up to $0.75 \mathrm{~m}$ has been observed in worked out sections, where pillars have been stripped. Access is required in the ore drives adjacent to these stoped out sections for up to 3 months after pillar stripping, during which time the lower stope pillars are stripped. The final stage involves wrecking of the upper ore drive pillars for bogging using hand-held remotes. An example of a worked out stope is shown in Figure 11, with a timber prop and sidewall slabbing giving an indication of the extent of the closure. The picture was taken looking down a slot rise, and the Threadbar and mesh support can be seen to be still intact, even with vertical closures of over $0.3 \mathrm{~m}$. 


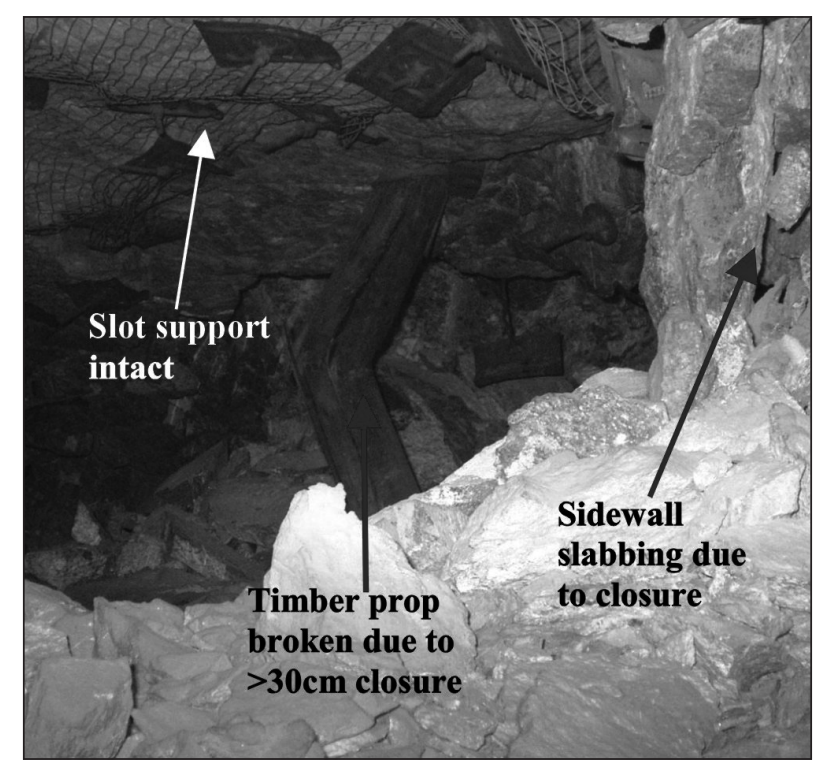

FIG. 11 Stope closure (looking down a stripped slot)

\subsection{Drive Closure}

Significant closure is observed in both the ore drives and the stope slots. Horizontal drive closure in the ore drives has been measured locally at up to $0.5 \mathrm{~m}$ following extraction of stoping and ore drive pillars. The Threadbar bolts in the backs and walls have remained intact even under such extreme deformation. Closure is measured using a telescopic convergence monitor.

Typical ore drive closure during the final pillar stripping stage is around $20 \mathrm{~cm}$, at which stage all Threadbar bolts installed in the ore drives are still functional. Contouring of ore drive closure monitoring results (Figure 12) shows that high closures are associated with areas of increased extraction, as expected.

The time-dependent mode of failure experienced at OtterJuan in the ultramafic rockmass is similar, but not as severe as that observed at the Perseverance Nickel Mine at Leinster, Western Australia (Struthers et al., 2000). Interestingly, Perseverance also use Threadbars in drives susceptible to severe closure, albeit de-bonded cement grouted units, but utilising the same elongation capacity of the steel to cope with the deformations.

Ore drive closure is not as clearly related to time (Figure 13), due to the different layouts per level, the presence of porphyry intrusives, additional flanking ore surfaces and large variations in mining rates. Ore drive closure is also affected by stoping on the other main ore surface, especially where the two surfaces are within $20 \mathrm{~m}$ of each other. From observations and seismicity in mined out sections, the ore drives (as well as stopes) continue to deform after mining operations have stopped.

An example of the successful performance of Threadbar bolts under extreme deformation is shown in Figure 14, which is a picture of the 35F1 hangingwall diamond drill drive, which suffered vertical closure of $0.5 \mathrm{~m}$ and horizontal closure of $0.7 \mathrm{~m}$ (1.2 m closure without Threadbars) over a period of 2 years. This drive remained serviceable for over a year, with the support system retaining the deforming rockmass and maintaining a safe working environment even under such extreme conditions.

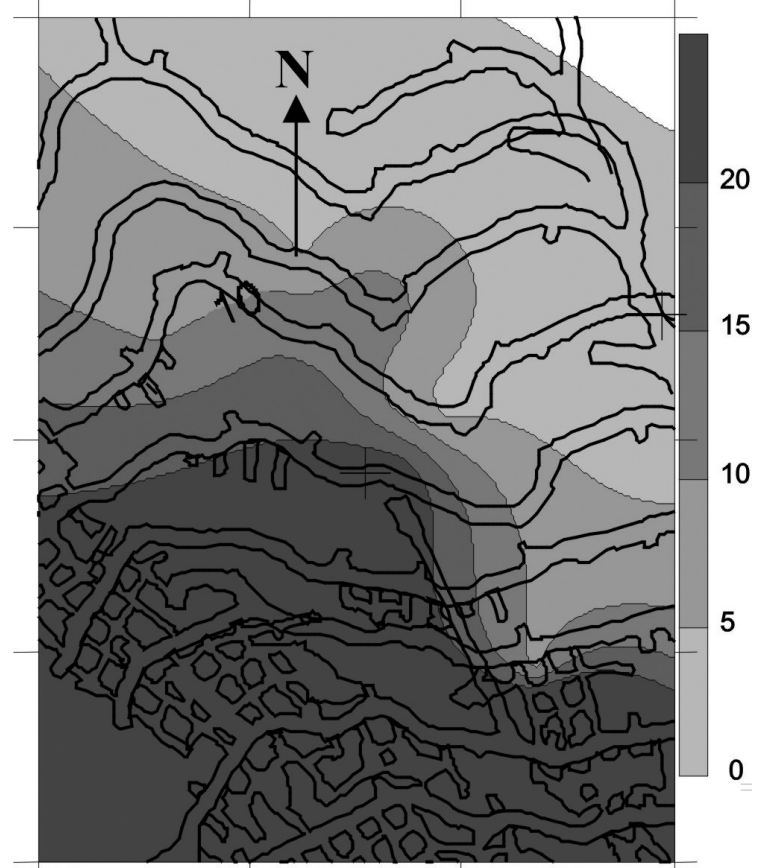

FIG. 12 Contour map of ore drive closure $(\mathrm{cm})$ in the lower Fsurface

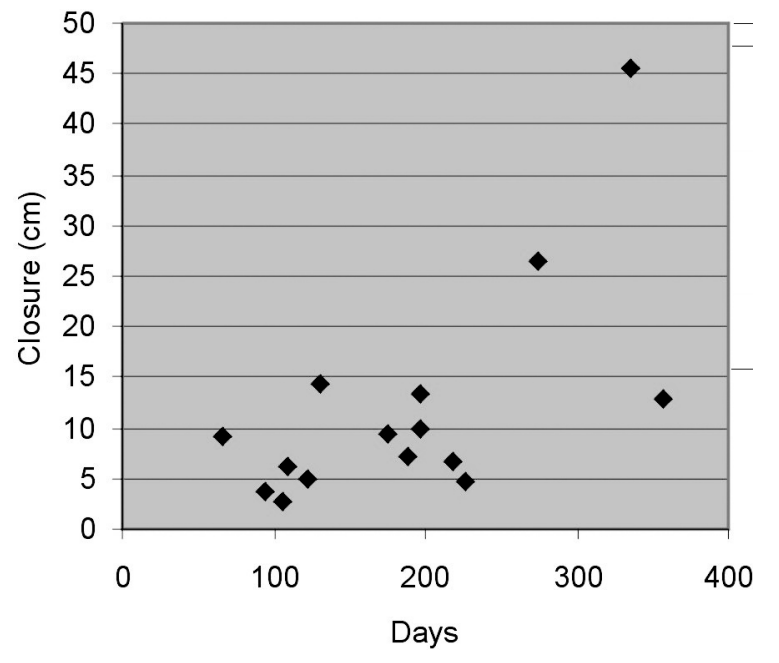

FIG. 13 Ore drive closures over time

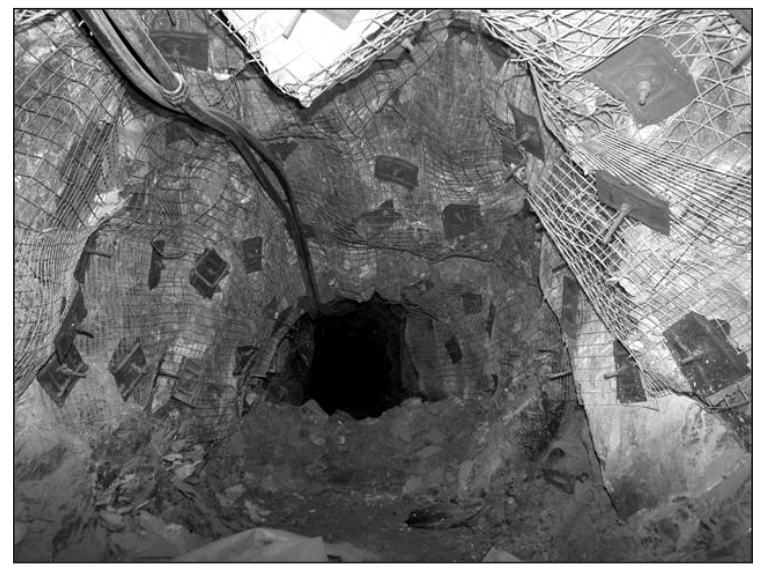

FIG. 14 Time Dependent Deformation, 35F1 Drill Drive 


\subsection{Extensometer Readings}

Extensometers installed into the ore drive backs have indicated that deformation is of the order of $70 \mathrm{~mm}$ within $2 \mathrm{~m}$ of the drive, during the time the instrument is installed to the final mining stage. The extensometers are only installed after the ore drive has reached the western limit. At that stage there is already evidence of deformation on the drive shoulders, back and walls and the mesh and split sets have started showing signs of load (mesh bulging, plates buckling, rings tearing). The results for extensometers installed in 34F1 and 32N1 ore drives are shown in Figure 15.

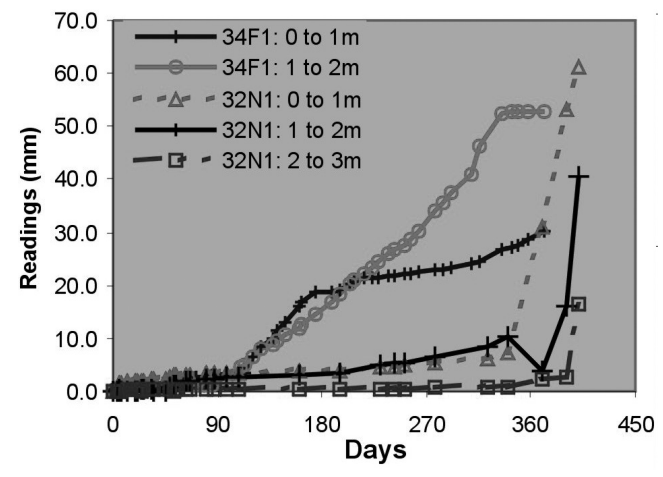

\section{FIG. 15 Extensometer data}

Such deformation for the first $2 \mathrm{~m}$ would easily be within the capabilities of Threadbar bolts and mesh, and from observations is beyond the capacity of many of the split sets.

\subsection{Numerical Modelling}

Map3D modelling (elastic and non-linear) has been undertaken to quantify the increase in plastic strain and excavation deformation from the current stoping depths of around $1150 \mathrm{mbs}$ to the estimated economic limit of around 1400 mbs. The increase in strain has been used to assess whether the current designs and support systems will be able to cope as the mine advances deeper.

Modelling results from the non-linear modelling (Figure 16) indicate that the increase in plastic strain is expected to be of the order of $50 \%$ (14 to $21 \mathrm{~mm} / \mathrm{m}$ ). The modelling has not yet been calibrated (e.g. reduction in modulus close to excavations) and the modelled strain of $14 \mathrm{~mm} / \mathrm{m}$ can be compared to the strain of $35 \mathrm{~mm} / \mathrm{m}$ measured in extensometers, i.e. a multiplication factor of 2.5. Scaling up the modelled strain results in a prediction for strain of $90 \mathrm{~mm} / \mathrm{m}$.

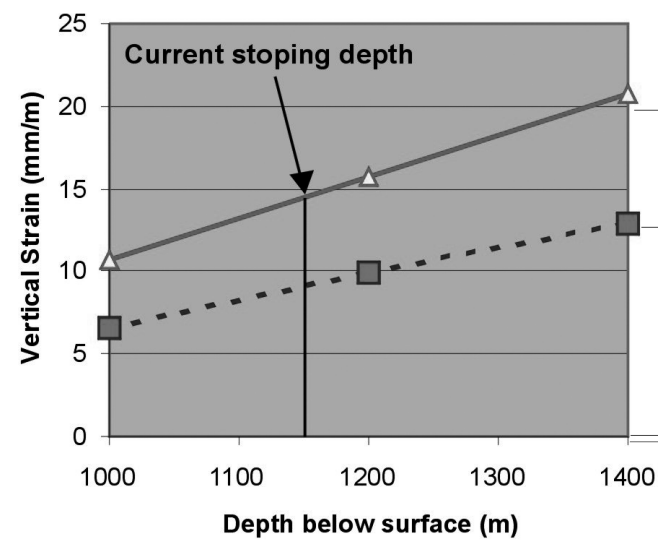

Slotting $\triangle-\Delta$ Stripping
The current support system based on Threadbar bolts is expected to cope with such an increase as the quoted bolt elongation capacity is $190 \mathrm{~mm} / \mathrm{m}$. There are currently no failures of Threadbars due to excessive elongation and observations confirm there is still a capacity for more deformation. The stoping also appears to be capable of coping with more deformation, although the dimensions of slots and drives might have to be reduced and overall extraction reduced by leaving pillar widths the same as currently used.

\subsection{Seismicity}

Mining induced seismicity has been reported at Otter-Juan since the 1980s. This has mainly been due to the effects of increasing stresses (virgin plus mining component) on stiff (e.g. massive sulphide) pillars.

An ESG microseismic monitoring system was installed in 1998 by WMC at Otter-Juan. The system currently comprises an array of 11 uniaxial accelerometers and 4 triaxial accelerometers. In WMC's final production year (1999), typically 40 events per day were being detected (Turner, 2001). In general, the rate of seismic activity at Otter-Juan Mine has been relatively quiet since re-opening in May 2001. Since November 2003, an average of between 3 and 4 events have occurred per day with the actual number of events ranging from 0 and 38 per day.

The reduction in seismic activity since GMM commenced mining activities can be attributed to a number of factors:

- a reduction in the width of the hangingwall span exposed in stopes

- a sequential mining sequence

- the use of yielding pillars.

The locations of the majority of recent seismic events now tend to be located in the ultramafic rockmass between the lower and upper ore surfaces. Incidences of pillar-related seismicity are now very infrequent as pillars yield as they are formed. On an annual basis (Figure 17) the seismicity can be seen to follow the stoping as stoping advances deeper.

Mining production prior to 2001 was more scattered, with more pillar related seismic events. The benefit of the current disciplined extraction sequence is that seismicity is reduced and more predictable. Extreme, high magnitude seismic events are therefore not expected and there is confidence that the current support systems can cope.

Much of the current activity has been associated with a porphyry intrusive which transects the relatively soft ultramafic host rocks from 32 to 38 Levels.

Small rockbursts have been observed along the margins of the porphyry (Figure 18) and within the porphyry (Figure 19) as stoping retreats towards the western porphyry contact. Estimates of the magnitudes of the events associated with the rockbursts range from $M_{L}=-0.5$ to $M_{L}=0$.

The Threadbar bolts have performed extremely well in the rockburst conditions and, with the mesh, have contained the broken rockmass very well, with no broken bolts. Many of the splits sets installed in and adjacent to these rockburst sites have failed.

Increased mining depths with associated stress increases are generally expected to lead to increased levels of smallscale seismic activity around excavations and along contacts between stiff porphyry intrusives and the weak ultramafic hangingwall rockmass.

Fortunately, the current porphyry intrusive does not intersect the orebody or access development below 38 Level and no further porphyries are expected. The rockburst 


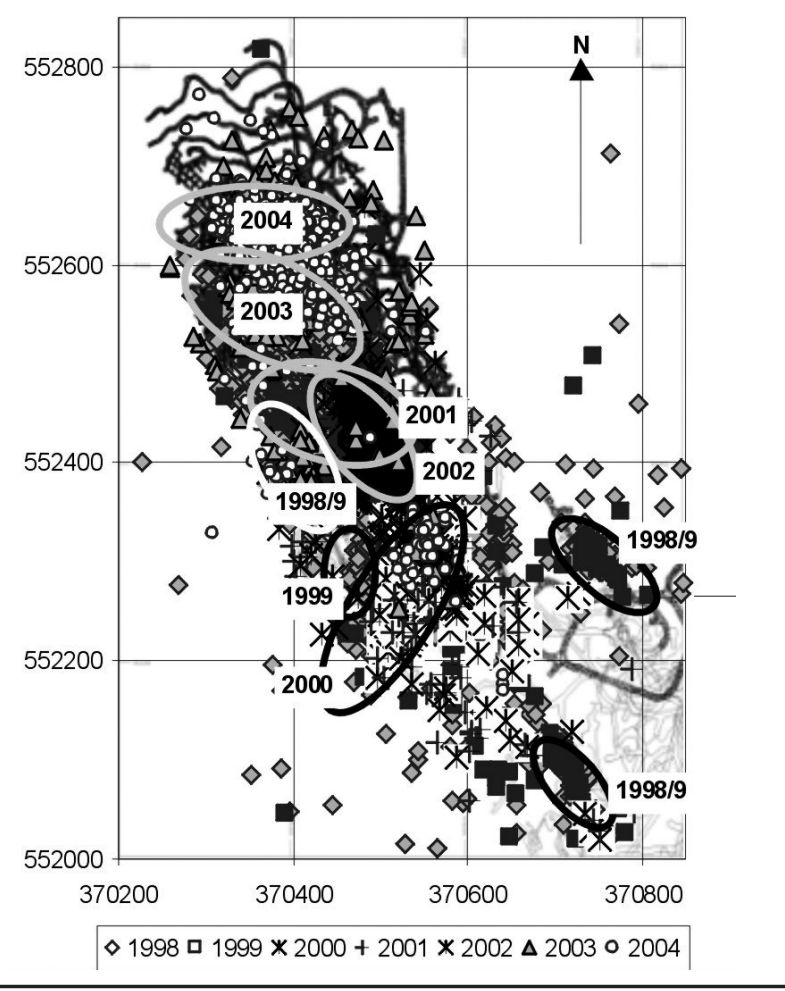

FIG. 17 Event clusters per year

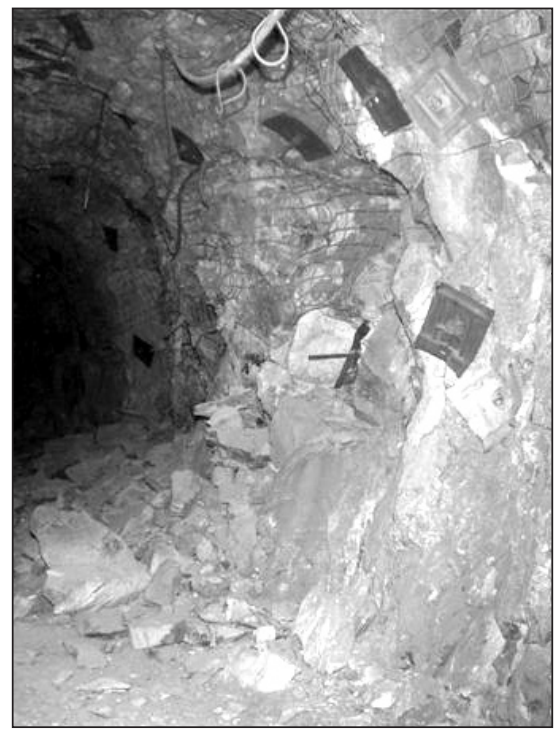

FIG. 18 Rockburst in 33N1 (porphyry), moderately controlled by support system - prior to wall meshing becoming standard in porphyry

incidents should therefore decrease below that level, leaving only the time dependent deformation component that the bolts have to cope with.

\section{CONCLUSION}

The Threadbar bolts have performed well under extreme conditions, coping with both time dependent deformation and seismicity. The elongation capacity of the Threadbars is sufficient for current conditions and measurements indicate that this capacity will also be sufficient for mining down to 1400 mbs. Only occasional Threadbar failures have been

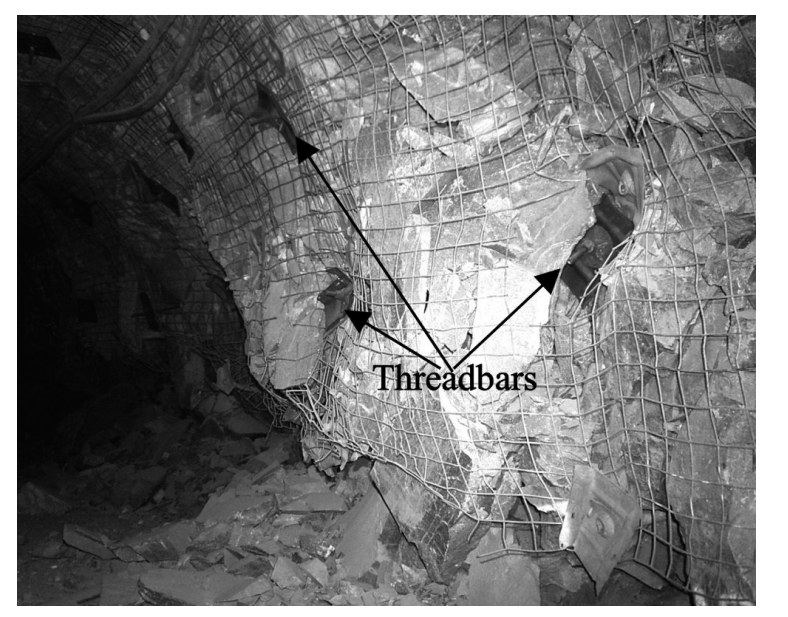

FIG. 19 Rockburst in 37F Ore drive (porphyry) controlled by support system

observed in the up-dip shoulders of ore drives, where the bolts have been clamped $0.5 \mathrm{~m}$ into the sidewall by rock movement associated with drive closures.

The current relatively low levels of seismicity are well within the capacity of the Threadbar bolts, with no failures due to rockbursts to date. It is yet to be seen, however, whether the bolts could cope with a larger event close to an excavation, where peak velocities and accelerations would be far higher than experienced to date.

The bolts have also proven far more resistant to blast damage than split sets and the installation of an additional plate can be used on existing bolts to install adjoining or replacement sheets of mesh.

The Threadbar bolts form the backbone of a relatively low cost and simple ground support system for mining at depth. The success of the support system has greatly improved the profitability of the mine by ensuring continued production and reduced hangingwall dilution.

The authors would like to thank Goldfields Mine Management Pty Ltd for providing the data for this paper and both GMM and AMC Consultants Pty Ltd for providing the time and resources required to write the paper.

\section{REFERENCES}

AMC (1998) Otter-Juan Nickel Complex, 31 Level Virgin Stress Measurement. Australian Mining Consultants report 198063, December.

Banasik, C. (2003) The Pitfalls Of Exploring A Shallow Dipping Orebody At Depth - A Case Study. Otter/Juan Mine, Kambalda, WA. In Proceedings 12th International Symposium on Mine Planning and Equipment Selection, April 23-25, 2003, Kalgoorlie, Western Australia.

DSI (2004) 20 mm Threadbar Bolts. Data Sheet A1.8, Dywidag-Systems International CD Product Catalogue, July.

Lee, M.F., Pascoe, M.J. and Mikula, P.A. (2001) Virgin Rock Stresses vs Rockmass Strength in Western Australia's Yilgarn Greenstones. In Proceedings Ground Control in Mines Workshop, The Chamber of Minerals and Energy, Perth, June.

Player, J. (2004) Reinforcement and Support Investigations for Static and Dynamic Loading Conditions at the Big Bell Sublevel Caving Operations, Unpublished Masters of Engineering Science Thesis, Western Australian School of Mines, March.

Struthers, M.A., Turner, M.H., McNabb, K. and Jenkins, P.A. (2000) Rock Mechanics Design and Practice for Squeezing Ground and High Stress Conditions at Perseverance Mine. In Proceedings MassMin2000, Australasian Institute of Mining and Metallurgy, Brisbane.

Turner, M.H. (2001) Otter-Juan Seismic Risk. AMC Report 201049 for GBF Underground Mining Pty Ltd. March.

Turner, M.H., Green, T. and Teasdale, P. (2004) A Step back in time to Hand Held Mining for Profitability. Proceedings 2nd International Symposium on Mining Techniques for Narrow-Vein Deposits, CIM, Val d'Or, Quebec, October. 